\title{
A Rational Distribution of General Administrative Law-Enforcing Powers in China's Urban Management
}

\author{
Jing Xiang \\ Law School \\ Sichuan University \\ Chengdu, China
}

\begin{abstract}
After entering a new period, the reform of administrative law enforcement for urban management shall be focused on the rational distribution of the law enforcing powers, clarifying the border between governments and markets, governments and the society, following the principles of doing under laws, coordination between vertical and horizontal powers, as well as integral distribution, the powers can be rationally distributed between the central government and local governments. The central government shall be devoted to the establishment of macro-policies and administrative regulations, and provincial governments responsible for decision-making, supervision and coordination, and the specific execution will be done by municipal and county people's governments.
\end{abstract}

Keywords-general law enforcement; law enforcing power; vertical power

\section{INTRODUCTION}

The reform of general administrative law enforcement in urban management in China (hereinafter called "the general law enforcement") started with the "Administrative Punishment Law of the People's Republic of China" promulgated in 1996 (hereinafter called as the "Administrative Punishment Law"), after about two-decade development, it has in some degree alleviated problems as power intersection and duplicate law enforcement and so on. However, many problems have not been solved fundamentally as numerous law enforcement agencies, decentralized power, process disconnection, unclear responsibilities and blocked systems, for which main reasons are that the reform of existing general law enforcement is based on the trap and block administrative system inherent in $\mathrm{China}^{1}$, the artificial distribution of horizontal power makes it worst to run the administrative system. Therefore, the future reform of the general law enforcement should be redistributed in the vertical general law enforcing power and redefine the general law enforcing powers between the central government, provinces, cities and counties.

\footnotetext{
${ }^{1}$ Trap refers to the functional departments which take charge of management of special affairs in cities; Block refers to governments of all levels which execute organization, leading, coordination, supervision and instruction to administrative affairs including urban management in the areas under administration.
}

\section{REDEFINE THE POWER OF THE CENTRAL} GOVERNMENTS IN THE GENERAL LAW ENFORCEMENT

In order to achieve the vertical distribution of the general law enforcing powers in urban management, first of all, it needs to define governmental functions and realize the rational distribution in the power between governments, market and society. Only after the matters that governments should be responsible are determined, can it be further determined for governments and departments. The Opinions on Deepening the Reform of Administrative Systems (2008) of the CPC Central Committee points out that it needs to speed up the separation of governments from enterprises, separation of governmental affairs from state-owned assets management, administrative units from institutions, governments from market agents, transfer the affairs which should not be administrated by governments, the affairs that governments should do shall be well done, and exert the basic roles of markets in the allocation of resources, and better exert the roles of citizens and social organizations in the management of social public affairs, and provide more effective public products. The affairs which can be solved through the market shall not be administrated by the governments, those that can be solved through the society shall be kept away from the administration of governments, and the roles of non-governmental organizations should be fully exerted. After more than 10 years of streamlining administration and delegating power, the governments have greatly reduced the power in the direct management on the market, and the governmental functions have been gradually limited to four areas namely economic regulation, market supervision, social management and public service.

The Communiqué of the Fifth Plenary Session of the 18th CPC Central Committee (2014) (hereinafter called the Communiqué) delimited the general law enforcement in urban management into the following: food and drug safety, quality inspection of industry and commerce, public health, safe production, cultural tourism, resources and environment, agriculture, forestry, water conservancy, transportation, urban and rural construction, marine fishery and so on. Some laws and regulations in these fields have emphasized the roles of self-governing organizations and social organizations in 
management, such as Article 9 stipulated in Food Safety Law of the People's Republic of China ${ }^{2}$, the Notice of the State Council on the Promotion of Reproducible Reform Pilot Experiment in China (Shanghai) Pilot Free Trade Zone ${ }^{3}$, the Opinions of the State Council on Promoting Fair Competition and Protecting Market Order ${ }^{4}$, etc. However, the laws and regulations are made in a low level, which are recapitulative, and some are even policy documents, and it still needs deeply study in specific fields the positioning of governments, markets and the society, foster the capabilities of markets and the society in urban management, achieve the coordination and cooperation between governments and markets, governments and the society in urban management in order for joint management and for a better result.

\section{POWER POSITIONING OF The CEnTRAL GOVERnMENT AND LOCAL GOVERNMENTS}

After clarifying the power of governments in urban management, it needs to determine the setup of administrative institutions as per administrative powers and specify administrative powers of governments at all levels. In accordance with the Decision of the Central Committee of the Communist Party of China on Some Major Issues Concerning Comprehensively Deepening the Reform (2013), the next step of vertical reform of the administrative system is to minimize the central government's administration on micro-affairs, the social and economic affairs directly to the grassroots level in a large scope which are much more efficient to be administrated by local governments should be delegated to the local and grass-roots for administration. Strengthen the central government's powers and capabilities in macro-control, and intensify the local governments' powers in public services, market supervision, social management, environmental protection and so on. The Decision of the CPC Central Committee on Major Issues Pertaining to Comprehensively Promoting the Rule of Law (2014) further points out that it needs to promote the standardization and legalization of government duties at all levels, improve the legal systems of governments at different levels especially the central and local governments, strengthen the central government's macro control, setup powers and necessary law enforcing powers, intensify the provincial governments to promote equalization of basic public services within the region, and strengthen the duties of municipal and county people's governments. On Aug

\footnotetext{
${ }^{2}$ Article 9 Food industry associations shall strengthen industry self-regulation, establish and improve industry norms and punishment and reward mechanisms in accordance with their respective articles of association, provide food safety information, technology, and other services, guide and supervise food producers and traders in legally engaging in production and trade, enhance integrity in the industry, and publicize and disseminate food safety knowledge.

${ }^{3}$ Notice of the State Council on the Promotion of Reproducible Reform Pilot Experiment in China (Shanghai) Pilot Free Trade Zone proposes that it needs to raise social strengths to participate in to market supervision, and support industrial associations and professional service agencies for market supervision via service purchase and establishment of standards.

4 State Council's Opinions on Promoting Market Fair Competition and Maintain Good Market Order stresses that it needs to strengthen the construction of industrial associations and chambers of commerce, improve the capability for market supervision, and accelerate the transfer of functions applicable for industrial associations and chambers of commerce.
}

16, 2016, the State Council formally issued the "Opinions for Reform on the Implementation of the Central and Local Fiscal Duties and Expenditure Responsibilities, which is a key measure for vertical power distribution between the central government and local governments. The top-level design clarifies that the goal of vertical reform of the administrative system is to rationally distribute the functions of the central and local governments, and change the problems as "upper and lower same in structure, upper and lower same in content" in the traditional administrative system. For the general law enforcement of urban management, it also needs to rationally delimit the functions of the central government and local governments, and establish an efficient general law enforcement system in urban management.

The "Opinions on Deepening the Reform of Administrative System" proposes that the central government should strengthen the macro-control over the economy and social affairs, further reduce and decentralize specific management issues, pay more attention to the establishment of strategic planning, policies and regulations and standards, protect the state legal unity, decree unity and market unity. Local governments should ensure the effective implementation of central policies and state laws and regulations, strengthen the uniform coordination of economic and social affairs in the region, strengthen the supervision on execution and law enforcement duties, ensure the service and management for the grassroots and the mass, protect the market order and social stability, and promote the economic and social development. As far as the urban management, the urban planning and construction, urban appearance and environmental sanitation, municipal and urban greening, environmental protection, cultural tourism, agriculture, forestry, water conservancy and transportation are mainly concentrated in the local governments, which should be combined with the actual characteristics of the local, so it belongs to the functions of local governments, to be solved by the local.

Article 89-4 stipulated in the Constitution of the People's Republic of China provides that the State Council shall have the power to specify the powers between the central government, provincial governments, autonomous regions, directly administrated cities, and the like; In accordance with Article 65-2 stipulated in the Law of the People's Republic of China on Legislation, the State Council has the power to formulate administrative rules and regulations on matters concerning administrative powers of the State Council in accordance with the Constitution and the laws concerned. Accordingly, under the existing laws and regulations, the vertical distribution of administrative powers between the central government and local governments is in full compliance with laws, besides, the State Council may rely on administrative laws and regulations to legalize the duties of the central and local governments. In addition, though the Administrative Punishment Law ${ }^{5}$, the Law of the People's Republic of China on Administrative Permission (abbreviated

\footnotetext{
5 Article 16 stated in the Administrative Punishment Law provides, the State Council or the people's government of a province, autonomous region or municipality directly under the Central Government that is empowered by the State Council may decide to have an administrative organ exercise other administrative organs' power of administrative penalty.
} 
as the Administrative Permission Law) ${ }^{6}$ and the Administrative Coercion Law of the People's Republic of China (abbreviated as the Administrative Coercion Law) ${ }^{7}$ are mainly involved in the horizontal centralization, but seen from the articles, they are not only limited to the horizontal power concentration, the concentration and distribution of vertical powers are also included. In addition, in accordance with the Decision of the State Council on Further Promoting the Work of Relative Concentration of the Authority of Administrative Punishments (2002), the people's governments of provinces, autonomous regions and municipalities directly under the Central Government may decide to carry out the work of relative concentration of the authority of administrative punishments within the administrative regions of their own and no longer need the approval of the State Council. Therefore, as far as the general law enforcement in urban management between the central government and local governments, the State Council can carry out macro direction and institutionalize and legalize it through administrative laws and regulations; provincial governments may consider the actual situations in the regions of their own to specify the general law enforcement in urban management.

\section{FunCtions Of LOCAL GOVERNMENTS DURING THE GENERAL LAW ENFORCEMENT}

In accordance with the Administrative Punishment Law, the Administrative Permission Law) and the Administrative Coercion Law, as well as provision of the State Council on the general law enforcement, provincial governments, autonomous regions and municipalities directly under the Central Government may, following relevant laws and regulations, decide on the vertical power division in the general law enforcement in urban management, namely providing powers of general law enforcement among provincial, municipal, county and township governments.

When providing the powers of general law enforcement for local governments, the provincial governments should abide by the following principles:

\section{A. Distribute Powers according to Laws}

First of all, according to clauses 99-1, 100, 105-1 stated in the Constitution ${ }^{8}$, the state authorities at provincial levels shall

\footnotetext{
${ }^{6}$ Article 25 stated in the Administrative Permission Law, provides, Upon approval by the State Council, the people's government of a province, autonomous region or municipality directly under the Central Government may, on the basis of the principles of simplification, uniformity and efficiency, decide to let one administrative organ exercise the powers of administrative permission which are exercised by relevant administrative organs.

${ }^{7}$ Article 17-2 of the Administrative Coercion Law, provides, Administrative organs which exercise relatively centralized powers of administrative punishment in accordance with the Law of the People's Republic of China on Administrative Punishment may implement administrative coercive measures related to their powers of administrative punishment as prescribed by laws and regulations.

${ }^{8}$ The Constitution of the PRC: Article 99 Local people's congresses at various levels ensure the observance and implementation of the Constitution and the law and the administrative rules and regulations in their respective administrative areas. Within the limits of their authority as prescribed by law, they adopt and issue resolutions and examine and decide on plans for local economic and cultural development and for the development of public
}

have the power to allocate the functions and powers of local governments at all levels within administrative regions of their own and develop local regulations. Therefore, during the allocation of power, the provincial governments shall regard the provisions concerning state authorities at provincial levels, can not go beyond the limits of authorities in the allocation of powers within the scope of state authorities at provincial levels. Without doubt, the state authorities at provincial levels should also fully regard the allocation of administrative powers of local governments. State authorities at provincial levels are mainly responsible for the major and comprehensive affairs within the administrative regions of their own, if the allocation of powers of general law enforcement in urban management belongs to great and systematic and comprehensive adjustment it shall be approved by the state authorities at provincial levels. But in case of local and in-system affairs, it should respect the decisions of the provincial governments, do not easily deny the power of the provincial government on the allocation of local administrative power. Second, in the allocation of local administrative powers by the provincial governments, it may be involved in redefining of administrative powers among municipal, county and township governments. According to clause 55 of the Organic Law of the Local People's Congress and Local People's Governments of the P.R. China (hereinafter called the Organic Law), local people's governments at all levels should be responsible for and make reports to the people's congresses at the same level and the above-level state authorities. Therefore, the municipal, county and township governments, in addition to the implementation of decisions and orders of the provincial government's, shall also be responsible for the state authorities at the same level. In the allocation of the local administrative powers to the municipal, county and township governments, the provincial governments should not go against the allocation of local administrative powers by the local state authorities. Finally, although the slip law has granted the provincial governments on the allocation of the administrative powers, yet, it shall not go beyond those which are kept in laws.

\section{B. Coordinate the Distribution between Vertical and Horizontal Powers}

The administrative powers are divided according to the trap and block in China, based on which, the network structure of

services. Article 100 The people's congresses of provinces and municipalities directly under the Central Government and their standing committees may adopt local regulations, which must not contravene the Constitution and the law and administrative rules and regulations, and they shall report such local regulations to the Standing Committee of the National People's Congress for the record.

${ }^{9}$ Article 16 stated in the Administrative Punishment Law provide, the power of administrative penalty involving restriction of freedom of person shall only be exercised by the public security organs. Article 17-2 of the Administrative Coercion Law, provides, Administrative organs which exercise relatively centralized powers of administrative punishment in accordance with the Law of the People's Republic of China on Administrative Punishment may implement administrative coercive measures related to their powers of administrative punishment as prescribed by laws and regulations. Article 17-1 provides, Administrative coercive measures shall be implemented by administrative organs prescribed by laws and regulations within their statutory authority. The power to implement administrative coercive measures shall not be delegated. The laws and regulations show the power allocation of provincial governments are limited, which must be done under laws. 
administrative management is established. The structure determines that the allocation of vertical powers should be coordinated with that of horizontal ones, otherwise it not only can not fundamentally change the administrative system of the blocks, but also will continue in the vicious cycle "streamline expand - re-streamline - re-expand", "disorder when loosing, tighten when disordering, fail when tightening". At present, the reform of the "county administered by province" and the "super ministry systems" is conducted from the vertical and the horizontal.

\section{Integral Allocation in Power and Function}

The trap and block-based administrative system makes the functions of urban management set from high-level to low level, which leads to the expansion of the administrative levels, decentralization of powers and the low efficiency in management. The goal of the new round of reforms in administrative system is to rationally allocate the law enforcement forces according to duties and functions of governments at different levels and following the principle of reducing levels, integrating teams and improving the efficiency. Seen from the rules of the general lawn enforcement in urban management, which are released in local regions, the provincial governments are mainly engaged in the decision, guidance, coordination and supervision. The general law enforcement agencies in urban management shall be mainly set up in cities, districts and counties, that is, the general law enforcement agencies in urban management are set up in urban areas and districts and counties. The district and county general law enforcement agencies in urban management will follow the leading of the city-level general law enforcement agencies in urban management, the functions of the governments at two levels are not clearly distinguished as between, both exercise the powers in urban management, municipal, greening, market management and so on, only different in the level, this function is almost the same as traditional administrative system. During the course of urban management, the problems as unlicensed vendors, occupation of roads and living noise and so on are directly related to district and county governments, which will be the most suitable for direct law enforcement, on the allocation of powers, they can be allocated to district and county law enforcement agencies in urban management, while no similar power will be allocated to the city-level general law enforcement agencies in urban management. However, such law enforcement as environmental protection and pollution prevention and control, it needs professional knowledge and equipment, and may be involved in the local economic interests at the grassroots level. It can be managed by the general law enforcement agencies at the county level or above, and no similar powers will be allocated to district and county level general law enforcement agencies in urban management. The Recommendations for the 13th Five-Year Plan for Economic and Social Development (2015) proposed a vertical management system of monitoring, inspection and law enforcement for environmental protection agencies below the provincial levels. Main changes include: the provincial environmental protection departments will directly manage the monitoring and supervision agencies in cities (local) and counties, undertaking the costs related to personnel and work, and the environmental protection bureaus at cities (local) shall implement the dual management system with the provincial environmental protection departments (bureaus) as the center, The county-level environmental protection bureau shall no longer be set up as a unit of that at the cities (local) and county-level. Seen from the environmental protection, the tightening of the functions aims to prevent local intervention and strengthen the environmental protection; analyzed from the administrative system, it can be considered that the environmental monitoring and investigation are exercised uniformly by the provincial environmental protection departments, and the power of law enforcement of the environmental protection is granted to the city(county) level environmental protection departments and the general law enforcement agencies in urban management. In the opinion of the author, the system design can be deemed as an attempt of transferring administrative functions and powers between local governments.

\section{CONCLUSION}

Speaking in details, during the transfer of functions of the general law enforcement in urban management for the city, county and township governments, it can be combined with the "country administrated by province" for reform, and the power of the general law enforcement in urban management will be centralized in the city and county governments for implementation. Since the year 2002, the "country administrated by province" reform has been conducted in the country as Zhejiang, Sichuan, Hubei and so on, and its main contents are to change the "provincial, city and county" threelevel administrative mode to a "provincial and municipal" or "provincial and county" two-level administrative management model, where the "city administrated by the province with county led" mode is changed to the city and county administrated by the province, so that the city and the county may develop at the same administration level. This reform is mainly concentrated on the "county administrated by the province" in the field of financial system, and the reform of "county administrated by the province" in the administrative system is launched gradually in Zhejiang and so on. The ultimate goal of the reform "county administrated by the province" is to make clear the functions and duties and financial powers of provincial, city and county level governments to exert the advantages of provincial, city and county level governments to maximize the decentralization and expansion of powers of the economic and social management and provide financial support for the city and county governments to fulfill duties of the economic and social management. In the field of the general law enforcement in urban management, with the division of city and county and the development at the same level, the power of general law enforcement which originally belongs to the municipal governments will be concentrated in the county governments which will assume more functions in the law enforcement the same as the municipal governments. In the regions where the district is administrated by the municipality, the district is no longer a first-level government, whose powers of general law enforcement will be allocated to the municipal governments ${ }^{10}$.

\footnotetext{
${ }^{10}$ Xu Jimin, Analysis of Value for Centralizing the Power of Administrative
} 
Without doubt, in the absence of the "county administrated by province" administrative decentralization, in accordance with the principle of integrity mentioned above, the city, district and county will exercise the powers of law enforcement respectively.

In addition, starting from the year 2005, Zhejiang, Guangzhou and other provinces have launched the reform of "develop towns via expanding powers; develop towns via streamlining administration". According to the Notice on the Pilot Program for the Reform of the Administrative System in Developed Towns issued by the State Commission Office of Public Sectors Reform, the Central Rural Work Leading Group, the National Development and Reform Commission, the Ministry of Public Security, the Ministry of Finance and the Ministry of Civil Affairs in 2010, main contents of the reform include: decentralize the administrative powers related to urban construction and management such as urban construction, environmental protection, public security and so on to townships. However, according to the Administrative Punishment Law ${ }^{11}$, townships have no legal power for administrative punishments, and the administrative management is executed only through administrative authorization, which, besides, must be specified in laws, rules and regulations. At present, there are no laws or regulations which clearly define the authority of urban management of townships, meanwhile, according to the overall thinking of the administrative system reform, the ultimate goal of "develop towns via expanding powers; develop towns via streamlining administration" is not to increase an administrative level through dividing the power of administrative law enforcement. With the acceleration of urbanization, the roles of township governments should be inclined to assume the functions of public service and achieve the autonomy of townships. Therefore, the township is unsuitable for being a general law enforcement agency in urban management.

\section{REFERENCES}

[1] Zhang Zhanbin, Study on Ways to Achieve Governmental-level Reform and County Administrated by Province [J], Research on Economics and Management 2007(4)

[2] Wei Hongying, Rationalization of Vertical Power Structure: Basic Ways for Harmonious Development between the Central and the Local Relations [J] Chinese Public Administration, 2008 (6)

[3] Xu Jimin, Reform of Local Administrative Systems and Construction Servcie-based Governments $[\mathrm{J}]$ Journal of Zhejiang Provincial Party School, 2009(2)

\footnotetext{
Punishment and Ways Selection[M], Administrative Law Association, Papers Collected in 2015 Annual Meeting, 2015,928-938

${ }_{11}$ Article 18 stated in the Administrative Punishment Law provides, in accordance with the provisions of laws, regulations or rules, an admi nistrative organ may, within the scope of its powers as prescribed by law, entrust an organization that meets the conditions stipulated in Article 19 of this Law with imposing administrative penalty. An administrative organ may not entrust other organizations or individuals with imposing administrative penalty. Article 20 Administrative penalty shall come under the jurisdiction of an administrative organ having the power of administrative penalty of a local people's government at or above the county level in the place where the illegal act is committed, except as otherwise prescribed by laws or administrative rules and regulations.
}

[4] Cui Hao, Kong Xiangsheng, Power Restriction: Cores for Legalization between the Central and the Local Relationship [J], Journal of Henan Administrative Institute of Politics and Law, 2009(3)

[5] Ma Bin, Xu Yueqian, Zhejiang Mode In the Evolution of County Administrated by Province: Ways for Gradual Reforms and Systems [J], Theory and Reform, 2010 (1)

[6] Dong Juan, Analysis on Administration for Canceling Sub-district Offices [J], Journal of Changchun Communist Party Institute, 2010 (2)

[7] Xu Jimin, Reform of Local Administrative Systems: Practice, Problems and Ways [J], Theory and Reform, 2012 (4)

[8] Yi Dingqiang, Analysis of the "County Administrated by Province" Reform through Constitution [J], Seeker, 2013(8)

[9] Xu Jimin, Yang Dan, Analysis of the "Develop Town via Power Expanding" Reform through the Law [J], Theory and Reform, 2014 (2)

[10] $\mathrm{Xu}$ Jimin, Analysis of Value for Centralizing the Power of Administrative Punishment and Ways Selection [J], Academic Forum, Vol. 2016. 